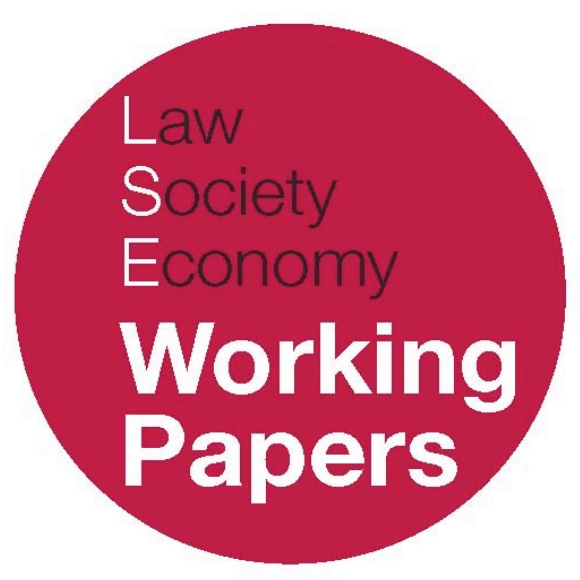

\title{
The Strange Death of Prerogative in England
}

\section{Thomas Poole}

LSE Law, Society and Economy Working Papers 21/2017

London School of Economics and Political Science

Law Department

This paper can be downloaded without charge from LSE Law, Society and Economy Working Papers at: www.lse.ac.uk/collections/law/wps/wps.htm and the Social Sciences Research Network electronic library at: http://ssm.com/abstract $=3083984$

(C) Thomas Poole. Users may download and/or print one copy to facilitate their private study or for noncommercial research. Users may not engage in further distribution of this material or use it for any profitmaking activities or any other form of commercial gain. 


\title{
The Strange Death of Prerogative in England
}

\author{
Thomas Poole
}

\begin{abstract}
This paper questions the continued existence of prerogative as a meaningful juridical category within UK constitutional law. It constructs a concept of prerogative out of canonical definitions, themselves instructive but incomplete, at the core of which is the idea of prerogative as a special category of executive power that evokes a special authority to which other political agents ought to defer. In light of recent prerogative cases, the paper advances two possibilities. A moderate reading suggests that prerogative has now become a special category of executive power that may evoke a special authority to which the court may in appropriate cases defer. A stronger reading advances the idea that prerogative is no longer a special category, but rather an inchoate set of executive capacities to which deference in general terms ought not to be given. It concludes by suggesting that we need to update our conceptual vocabulary. Just as we now speak about the executive's general administrative powers of contract and agency, we should prefer the terminology of the general executive powers of government to the vocabulary of royal prerogative.
\end{abstract}

\footnotetext{
* Professor of Law, London School of Economics \& Political Science. I would like to thank the participants at the workshop on executive power held in Perth at the Institute of Advanced Studies, University of Western Australia in April 2017, particularly to Murray Wesson for organising the workshop and the Honourable Robert French AC for his comments on the original paper. I would also like to thank Robert Craig for his comments on a later draft.
} 


\section{INTRODUCTION}

There are more important sources of political authority, but prerogative may still represent the apotheosis of executive power. Parliament has successfully chipped away at prerogative powers for centuries and the courts have done much to bring them further into the constitutional fold. Since there has been no wholesale abolition of prerogative, to suggest the end of prerogative may seem foolhardy in the extreme But it is just this line of inquiry that this paper proposes. Prompted by a quartet of UK Supreme Court cases that question the extent to which prerogative can still be said to operate as prerogative, it pursues as a kind of thought-experiment the proposition that what we are witnessing may not be the continued declension of prerogative so much as its incipient demise.

The more that argument succeeds, the more it diverges from previous analysis of the subject, including my own, which observed attempts by the courts in particular to normalise prerogative while noting the deference to government that still characterised prerogative cases. While the prerogative might be ordinary in principle, it remained special in practice. ${ }^{1}$ What is apparent in the more recent jurisprudence is the almost complete absence of deference afforded to the category by the courts. So emptied, prerogative begins to look like any other executive power, especially since the national security terrain on which it often presents is increasingly subject to scrutiny by courts and other institutions on something close to ordinary principles. Indeed, pleading prerogative might even have the opposite effect from the one intended, putting the court more on guard than it otherwise might have been. Far from being the trump card it may have been once, prerogative may now be something of a liability for those charged with defending governmental action.

There is value in pressing this case. But I also offer a fall-back position that accepts the continued existence of prerogative as a distinct, formal source of authority but tries to make sense of it given the demystification that has occurred in respect of both the prerogative category itself and the substantive claims for special powers in the interests of salus populi with which it was once conjoined.

Either alternative rests on assumptions about public law method. To get the argument going, I put both on the table now. The first assumption is that conceptual analysis in public law cannot just be about legal doctrine. Public law concerns how state power is instituted and exercised. To study a public law concept requires an account not just of what judges and jurists have said about it, but also an account of how what they said fits within the broader juristic framework of constitutional politics. It involves questions of jurisdiction but also of justification. Certainly, this

\footnotetext{
1 Thomas Poole, 'Judicial Review at the Margins: Law, Power and Prerogative' (2010) 60 University of Toronto Law Journal 81. See also, from a slightly older vintage, Adam Tomkins, Public Law (Oxford: Oxford University Press, 2003), 83: 'That the courts are prepared to grant to the Crown such elastic and ill-defined powers, and to subject their exercise to such modest - even superficial - review, constitutes the second way in which the executive will find the rule of law a much less onerous check on its powers than it might at first have seemed.'
} 
is true of prerogative. A longue durée concept, ${ }^{2}$ prerogative is associated with sovereign capacities - war and peace, foreign relations, and empire - and touches on fundamental questions about trust and the generation of political authority. To read only the cases is to miss much of what is important about the concept.

The second assumption is that this style of conceptual analysis tends to take the form of a conversation between the present and the past. Most public law argument is situated, adopting an internal point of view to its subject. It may be more or less normatively committed, but its concern is with this political community and the ragbag of institutions, processes and norms - or what passes for constitutional wisdom - that makes it what it is. This is not nativist dogma - one can adopt an internal point of view without necessarily being an insider or participant. ${ }^{3}$ Nor does it devalue the contribution of comparative or more general philosophical inquiries, not least because these living traditions of thought and practice are not hermetically sealed and inspiration can be drawn from many sources. It is merely to observe the traditionality of much of what we do, our imbrication within juridical structures that involve the authoritative presence of transmitted, real or purported past'. ${ }^{4}$ Other things being equal, public lawyers have a responsibility to cultivate the juristic tradition in which they operate. Their enterprise is a species of practical reason that entails the refraction of received juristic material in light of the concerns of the present.

\section{THREE CONCEPTIONS OF PREROGATIVE}

I suspect I am not alone in finding the usual definitions of prerogative deficient. There must be something in them for us to go back to them so often. But the intuition developed in the first part of the paper is that each definition identifies an important aspect of prerogative but does not manage to capture the essence of the whole. I intend to sift through these conceptions in order to derive what I call a central case of prerogative, which I later hold up against current practice. ${ }^{5}$ This process of exposition, criticism and recovery - of disassembling key parts of the existing conceptual apparatus in order to reassemble them more satisfactorily - is somewhat stylised, and may entail drawing sharper contrasts between certain positions than a more orthodox textual treatment might allow.

When speaking about prerogative we tend to remark first on how difficult it is to pin down - 'a term which has caused more perplexity to students than any other

\footnotetext{
${ }^{2}$ For a defence of the study of which in the discipline of the history of ideas see Jo Guldi and David Armitage, The History Manifesto (Cambridge: Cambridge University Press, 2015).

3 See Scott J. Shapiro, 'What is the Internal Point of View' (2006) 75 Fordham Law Review 1157, $1158-61$.

4 Martin Krygier, 'The Traditionality of Statutes' (1988) 1 Ratio Juris 20, 21; Krygier, 'Law as 'Tradition' (1986) 5 Law and Philosophy 237, 240.

${ }^{5}$ For an elaboration of this method of sifting - and its application on a much more ambitious scale - see e.g. Alan Brudner, Constitutional Goods (Oxford: Oxford University Press, 2004).
} 
expression referring to the constitution', 6 Dicey wrote - and on the incense-laden air of sanctity that surrounds it. ${ }^{7}$ It is as if we feel compelled to undergo ritual obeisance at the threshold of Blackstone's altar of the bona dea ${ }^{8}$ before moving on to questions of substance. We now perform this ritual self-consciously and semiironically, ${ }^{9}$ a display of worldliness that only partially convinces, and I suspect that the numinous quality is part of the central case of prerogative.

Genuflection performed, our navigation of prerogative generally involves the interplay of three canonical statements or conceptions. These are more at variance with each other than we sometimes assume. In this game of competing definitions, it is Dicey's that predominates. He describes prerogative as 'the remaining portion of the Crown's original authority' and therefore 'the name for the residue of discretionary power left at any moment in the hands of the Crown, whether such power be in fact exercised by the King himself or by his Ministers'. ${ }^{10}$ While illuminating in certain respects, the definition is incomplete. For one thing, it does not distinguish prerogative from third-source power, ${ }^{11}$ but perhaps there is no real difference between them. ${ }^{12}$ More importantly, it does not get us much beyond the genuflection stage, ${ }^{13}$ though it does go some way towards describing the space in which prerogative operates. What it does usefully express, as I explain, is the idea of prerogative as a symbol. We can draw from Dicey the proposition that prerogative is essentially the residue of royal authority. It is a special sort of power that draws on the traditional or charismatic authority in principle embodied in the King. ${ }^{14}$ 'Between "prerogative" and "privilege" there exists a close analogy'.15

\footnotetext{
${ }^{6}$ A.V. Dicey, The Law of the Constitution (Oxford: Oxford University Press, ed. J.W.F. Allison, 2013), 188.

${ }^{7}$ Lord Roskill said that with prerogative he could hear (quoting Lord Atkin in United Australia Ltdv Barclays Bank Ltd [1941] AC 1, 29) 'the clanking of medieval chains of the ghosts of the past': Council of Civil Service Unions v Minister for the Civil Service [1985] AC 374, 417.

8 Blackstone, Commentaries I.7, 230.

${ }^{9}$ I go on to argue that we are inclined no longer to do it at all. See e.g. Lord Carlile v Secretary of State for the Home Department [2014] UKSC 60, [150] (Lord Kerr): 'Although we must accord the Secretary of State's view on this issue due deference, we are not required to genuflect in its presence.' And that the prerogative with no trace of residual majesty is no longer really prerogative.

10 Law of the Constitution, 189.

${ }^{11}$ Law of the Constitution, 189: 'Every act which the executive government can lawfully do without the authority of an Act of Parliament is done in virtue of its prerogative.'

12 Although the 'general administrative powers' of the Crown were recognised authoritatively in $\mathrm{R}$ (New College London) v Secretary of State for the Home Department [2013] UKSC 51, [28] (Lord Sumption). See also $\mathrm{R} v$ Secretary of State for Health, exp C [2000] HRLR 400 (CA); Town Investments Ltd v Department of the Environment [1978] AC 359. Much of the day-to-day business of government falls under such powers, which include the power to form contracts to the power to convey property, and powers to circulate written material, consult with officials, give gifts, and create policies. For discussion see Bruce Harris, 'The Third Source of Authority for Government Action' (1992) 108 Law Quarterly Review 626; Adam Perry, 'The Crown's Administrative Powers' (2015) 131 Law Quarterly Review 652.

${ }^{13}$ Lord Reid made a similar criticism in Burmab Oil Company v Lord Advocate [1965] AC 75, 99, saying that Dicey's definition 'does not take us very far'.

14 On which see e.g. Ennst H. Kantorowicz, The King's Two Bodies: An Essay in Medieval Political Theology (Princeton: Princeton University Press, 1995); Kenneth Pennington, The Prince and the Law, 1200-1600: Sovereignty and Rights in the Western Legal Tradition (Berkeley: University of California Press, 1993).

${ }^{15}$ Law of the Constitution, 190.
} 
We need to handle this insight carefully. Dicey noted how this authority had moved away from its original source. He always connected the prerogative of his day to the abstract entity of the Crown ${ }^{16}$ and not, as Blackstone tended to do, to the person of the monarch. He also said that those prerogative 'powers now left in the hands of the Crown' are 'exercised in fact by the executive government'. ${ }^{17}$ And he acknowledged that the executive officers of government, while formally the Queen's servants, in fact derive authority from a different source. As he wrote, in a discussion of conventions, ' $[\mathrm{t}$ ] heir end is to secure that Parliament, or the Cabinet which is indirectly appointed by Parliament, shall in the long run give effect to the will of that power which in modern England is the true political sovereign of the state the majority of the electors, or (to use the popular though not quite accurate language) the nation. ${ }^{18}$

This is the background against which we must interpret the pivotal but elusive phrase in his definition where prerogative is defined as the 'residue of [royal] discretionary authority'. Dicey pinpoints the idea of residue as crucial to understanding prerogative. But the term can be read more or less expansively. It might be read as saying simply, but not especially insightfully, that surviving prerogatives operate on a more restricted range than they once did, say under the Stuarts. ${ }^{19} \mathrm{I}$ prefer a broader reading that also takes Dicey as saying that in those extant prerogatives, we encounter a past world structured according to different political imperatives and principles. While prerogative continues to exist in attenuated form in the era of representative government and the rule of law, ${ }^{20}$ this reading suggests its true home remains the age of kings. Prerogative is the unpurged relic of lordship within our constitutional structures. With it, we come face to face with a political model that relied on twin medieval or 'Gothic' bases: control of territory (warlord) and control of land (overlord). ${ }^{21}$ This broader reading, which makes Dicey much less comfortable with prerogative than he is often made to appear, has the merit of bringing his definition of prerogative closer to his hostile position on martial law, increasingly prominent in later editions of the Law of the Constitution, which denied the executive any special prerogative capacity to declare martial law in time of peace. ${ }^{22}$

16 Martin Loughlin observes that although the idea of the Crown as a legal symbol of public power serves to differentiate between an institution of government and the personality of Her Majesty. But our related inability to distinguish properly between the State, Her Majesty and the Crown also entails that on fundamental issues our law is 'thoroughly ambiguous': 'The State, the Crown and the Law' in Maurice Sunkin and Sebastian Payne (eds), The Nature of the Crown: A Legal and Political Analysis (Oxford: Oxford University Press, 1999), 38-39.

17 Law of the Constitution, 39.

18 Law of the Constitution, 191.

19 This corresponds to Sebastian Payne's interpretation of Dicey on prerogative, which he calls 'entirely descriptive and retrospective': 'The Royal Prerogative' in Sunkin and Payne, The Nature of the Crown, 94.

20 See Law of the Constitution, 39.

21 The original (and best) analyst of the Gothic constitution and its structural presuppositions was James Harrington: see The Commonwealth of Oceana and A System of Politics (Cambridge: Cambridge University Press, ed. J.G.A. Pocock, 1992), 53-62.

${ }^{22}$ Law of the Constitution, 161-64 (First Edition) \& 352-66 (Sixth Edition). See also David Dyzenhaus, 'The Puzzle of Martial Law' (2009) 59 University of Toronto Law Journal 1. 
John Locke provides the second conception of prerogative. His account remains idiosyncratic ${ }^{23}$ and some may cavil about its inclusion here. But we frequently return to Locke on prerogative. ${ }^{24}$ I suspect we do so in part because of the canonical status of the Two Treatises of Government and its author's unparalleled reputation among English writers on the liberal constitution. But prerogative also provided Locke with a category through which he could explore foundational conditions of legitimate rule within the constituted polity, and specifically the nexus between (executive) authority and (popular) trust. Though Locke does not provide a narrowly legal account of prerogative - for that we would turn to his contemporary Sir Matthew Hale 25 - his theory is nonetheless juristic in its willingness to articulate how the prerogative might fit within the legal, institutional and normative architecture of the modern state patterned along English lines.

For Locke, prerogative was essentially a power to command that operates outside and against the laws, extra et contra legem. The Prince, whether monarch or republican leadership, holds this power in reserve for use where the laws run out, ${ }^{26}$ most notably in times of war or public emergency. ${ }^{27}$ This account highlights that prerogative is to be distinguished by its form and that what is distinctive about it is its formlessness. ${ }^{28}$ It is a reserve power - in contrast to Dicey's residual power - that operates as a kind of shadow to normal legal authority. 'This Power to act according to discretion, for the publick good, without the prescription of the Law, and sometimes even against it, is that which is called Prerogative. ${ }^{29}$ What is characteristic about prerogative, Locke suggests, is that the agent who exercises it does not derive authority to act from the normal legal source (typically statute) or by engaging the process associated with that source (typically parliamentary debate and assent). The Prince derives this special power directly from his capacity as supreme executive agent, drawing on that wellspring of power as need arises, in order to fulfil his

${ }^{23}$ Not least in the way it seeks to separate the domestic ('prerogative') and foreign ('federative') aspects of the power: see John Locke, Two Treatises of Government (Cambridge: Cambridge University Press, ed. Peter Laslett, 1988), II, Chs XII \& XIV.

24 A recent example is Timothy Endicott, 'Parliament and the Prerogative: From the Case of Proclamations to Miller' (1 Dec 1016, Judicial Power Project).

25 Sir Matthew Hale, Prerogatives of the King (London: Selden Society, ed. D.E.C. Yale, 1976).

${ }^{26}$ Locke's account of the scope of this power is, to modern eyes, extraordinarily broad: 'the Executor of the Laws, having the power in his hands, has by the common Law of Nature, a right to make use of it, for the good of the Society, in many Cases, where the municipal Law has given no direction, till the Legislative can conveniently be Assembled to provide for it. Many things there are, which the Law can by no means provide for, and those must necessarily be left to the discretion of him, that has the Executive Power in his hands, to be ordered by him, as the publick good and advantage shall require': Second Treatise, Ch. XIV, s.159.

${ }^{27}$ It is a remarkable, if little noted, how close this aspect of Locke's theory mirrors a standard distinction in scholastic thought, derived from Roman Law, between imperium, the ruler's exceptional and ultimate authority, which was not subject to law; and iurisdictio, or the ruler's routine decisions, which remain subject to law. On the distinction see e.g. Michael Wilks, The Problem of Sovereignty in the Later Middle Ages (Cambridge: Cambridge University Press, 1964), 209.

${ }^{28}$ Making a similar point about Locke's theory, Clement Fatovic talks about the 'informality of prerogative': Outside the Law: Emergency and Executive Power (Baltimore: Johns Hopkins University Press, 2009), 52-55.

29 Second Treatise, Ch. XIV, s.160 (italics in the original). 
obligation to secure the public interest (salus populi). Prerogative engages, that is to say, the Prince's capacity as guardian of the state - what Cicero called custodes patriae. ${ }^{30}$

The tendency among common lawyers like Hale had been to carve up and classify prerogative into a bundle of particular, bespoke prerogatives, a familiar strategy of disaggregation and normalisation. ${ }^{31}$ Locke's instincts ran in the opposite direction. He wanted to draw attention to what he took to be prerogative's juridically exceptional nature. Locke must have been aware that this approach entailed risks for his political project of patterning political association according to settled and standing laws structured on a fiduciary relationship between government and governed. His chapter on prerogative offers a reflection on the limits of that model. He assumes that there must be a space beyond the realm of settled and standing laws and that the products of that space must, by definition, take non-legal shape. 'Prerogative is notbing but the Power of doing publick good without a Rule.'32 It exists in the realm of decision and action - echoes of Carl Schmitt are inescapable ${ }^{33}$ - as opposed to deliberation and coordinated norm-production. Locke, enemy of the late Stuarts, ${ }^{34}$ is naturally alert to prerogative's dangers. He develops a politicaltheological narrative of trial and judgement where the assertion of prerogative tests the bonds of trust between sovereign and subject. His radical status is confirmed by an embrace of the potential upside of such moments of conflict-pregnant possibility that may produce disintegration, but may equally lead to political and spiritual renewal. But Locke's key conceptual insight is that prerogative denotes a legally unstructured species of authority that is a necessary and prior condition of rulebound civil association.

The third conception derives from Blackstone, whose name has already cropped up in the company of those who highlight the symbolic or affective element of prerogative. That is appropriate, for it was not idly that contemporary critics called him 'prerogative lawyer', 35 and he set value on the Gothic dimensions of English law and politics. ${ }^{36}$ But Blackstone also brings out a third element of prerogative. Consider this famous passage in the Commentaries, obliquely referenced earlier, where prerogative is described as:

30 Marcus Tullius Cicero, De Re Publica I. XLI. 64 (Cambridge, Mass: Harvard University Press, ed. Clinton Walker Keyes, 1928), 94.

31 A not dissimilar strategy was also deployed in cases on prerogative from at least the time of Bates's Case (1606) 2 State Trials 371.

32 Second Treatise, Ch. XIV, s.166.

33 See in particular Carl Schmitt, Political Theology - Four Chapters on the Concept of Sovereignty (Chicago: University of Chicago Press, ed. George Schwab, 1985).

34 On which see Richard Ashcraft, Revolutionary Politics and Locke's Two Treatises of Government (Princeton: Princeton University Press, 1986).

35 Wilfrid Prest, William Blackstone: Law and Letters in the Eighteenth Century (Oxford: Oxford University Press, 2008), 144.

${ }^{36}$ Even in the context of prerogative, where he wrote that the limitation of the regal authority was a first and essential principle of all the Gothic systems of government established in Europe; though gradually driven out and overborne, by violence and chicane, in most of the kingdoms on the continent' but not in England: Commentaries, I, 231. 
[a] topic, that in some former ages was thought too delicate and sacred to be profaned by the pen of a subject. It was ranked among the arcana imperii; and, like the mysteries of the bona dea, was not suffered to be pried into by any but such as were initiated in its service; because perhaps the exertion of the one, like the solemnities of the other, would not bear the inspection of rational and sober inquiry. ${ }^{37}$

There is mocking, sardonic note to this, without question, 38 yet it still reinforces the now familiar idea of prerogative as tied to the dignity of the King, and his status as basileus or imperator. ${ }^{39}$ But Blackstone relates another essential idea, and this is that prerogative is a special type of authority claim. The claim has two parts. First, a claim of special power that is a mark of sovereignty - and it is for that reason that prerogative is 'singular and eccentrical' 40 - but even so, would not otherwise be within the sovereign agent's capacity to act. Second, a claim of special jurisdiction, that is, a power for the sovereign agent to determine whether that exercise of power is legitimate. ${ }^{41}$ As Blackstone elaborated, 'in the exertion of lawful prerogative, the king is and ought to be absolute; that is, so far absolute, that there is no legal authority that can either delay or resist him.' ${ }^{42}$ Note that Blackstone sees both elements I have highlighted as of equal importance. On one hand, prerogative is not legally unconstrained and must be sanctioned by law. 43 On the other, if a prerogative is sanctioned by law the Sovereign is largely free to act within lawful bounds as he sees fit in the public interest. It is here, in conjunction with this two-headed claim of exceptional right, that the reverence that enwraps prerogative - all that wariness and unworthiness, ${ }^{44}$ the unfathomable numinousness - has real constitutional bite, for the 'very strength of the prerogative lay in its vagueness, for to define was to limit.'45

It is tempting to see this definition as simply expressing in different language Locke's point about the essential juridical otherness of prerogative. True, there are

37 Commentaries I, 230-1.

38 All the more so given the unmistakable echo of James I's divine right defence of prerogative, and the secrecy that he thought ought to attend it, which Blackstone quotes in the same passage. See 'The Trew Law of Free Monarchies', 74-5 and especially 'A Speech to the Lords of Commons of the Parliament' (22 March 1610), 190-1 in King James VI and I, Political Writings (Cambridge: Cambridge University Press, ed. Johann P. Sommerville, 1994).

${ }^{39}$ Commentaries, I, 235.

40 Commentaries, I, 239.

${ }^{41}$ See e.g. The Zamora [1916] 2 AC 77 (Privy Council): 'Those who are responsible for the national security must be the sole judges of what the national security requires.' (Lord Parker at p. 107). Although the court went on to reject the Crown's claim 'because the [Prize Court] judge had before him no satisfactory evidence that such a right was exercisable' (p.108).

42 Commentaries I, 243.

43 Indeed, this is how Blackstone starts the chapter in the Commentaries on the King's prerogative, repeating a claim made in the first chapter about the 'bounds so certain and notorious' that protect civil liberty from the royal authority: Commentaries I, 230.

44 See Darnel's Case (Five Knights Case) (1627) 3 How. St. Tr. 1, 13: 'We are too wise, nay, we are too foolish in undertaking to examine matters of State to which we are not born.'

45 Brian Levack, The Civil Lawyers in England, 1603-41: A Political Study (Oxford: Oxford University Press, 1973), 98. 
connections between the two accounts, but whereas Locke's theory is primarily political - indeed it interrogates foundational questions of obligation, force and right - Blackstone's enquiry is essentially constitutional. Blackstone sees prerogative as the special preserve of constitutional grey areas. In as much as it is outside the remit of the ordinary law, it stays within the constitution. The prerogative claim revealed in the last paragraph remains a claim to intra-constitutional authority rather than extra-constitutional action. It operates with the cognisance of the legal constitution even if it neither derives its legitimacy entirely from that quarter, nor comes fully under its jurisdiction. For Blackstone, prerogative power comes nested within law and institutional structures more firmly and squarely than Locke's theory seems to allow. 'I shall not (I trust) be considered as an advocate for arbitrary power, when I lay it down as a principle, that in the execution of lawful prerogative, the king is and ought to be absolute'. ${ }^{46}$ Both writers think that prerogative is essential for a functioning political order. But Locke is attracted to what he takes to be prerogative's extra-legal core, a precondition for political existence and the name we give to the political space in which basic authority is asserted and tested. Blackstone instead takes as defining prerogative's mediating capacity, regarding its skilled and prudential use as essential to preserving the balance of the constitution - or rather a series of balances, between law and politics, decision and deliberation, action and norm, king and parliament. When 'balanced and bridled', he claimed, prerogative 'invigorates the whole machine, and enables every part to answer the end of it's construction'. ${ }^{47}$

\section{THE CONCEPT OF PREROGATIVE}

So, what is prerogative? Three conceptions dominate, each suggestive but incomplete. The first (Dicey) sees prerogative as a residual power, expressive of the old marks of kingship some of which continue to operate in a changed world. The second (Locke) expresses an idea of prerogative as a plenary reserve power for use by the Prince when the law runs out or obstructs the public interest. The third (Blackstone) sees prerogative as a distinct juristic claim to special power and special jurisdiction and, revelling in its Gothic pedigree, suggests that the aura that encodes prerogative serves a useful function, freeing the Sovereign to act where necessary, so as to rebalance the constitution.

Each conception tends to spotlight a different analytic property. The first conception's idea of prerogative as the patrimony of kings, when played out in a constitutional monarchy that is effectively a republic in dress-up clothes, ${ }^{48}$ ends up

\footnotetext{
46 Commentaries I, 243 (emphasis added).

47 Commentaries I, 233.

48 I suspect that this idea that the UK is a monarchy in name only has been the dominant view among students of the UK constitution since at least Bagehot's The English Constitution (Cambridge: Cambridge University Press, ed. Paul Smith, 2001). But that perspective already had a long pedigree, a seminal
} 
emphasising prerogative's symbolic or affective aspects. The second conception of prerogative as an open-ended power that allows the Prince to act outside law draws attention to questions of form, specifically to its (at least relatively) informal nature. The third conception, like the first, highlights prerogative as a symbol but it does so the better to explain its functional role, understood as engaging a set of constitutionally permitted sovereign capacities.

Table 1: Conceptions of Prerogative

\begin{tabular}{|l|l|l|l|}
\hline & Nature & Figure & Element \\
\hline Dicey & Residual & Crown & Symbol \\
\hline Locke & Reserve & Prince & Form \\
\hline Blackstone & Discretionary & $\begin{array}{c}\text { Constitutional } \\
\text { Monarch }\end{array}$ & Function \\
\hline
\end{tabular}

This is the material out of which I construct the central case of prerogative. By 'central case' I mean more than concentrating on core prerogative capacities (such as war and peace, foreign relations, some aspects of citizenship, defence of the realm), though this is where my attention is focused. My working premise has been that the three authors addressed so far are on to something and deserve to be taken seriously. So, I intend to preserve as much as is valuable in the three conceptions, especially where they can be said to cohere. Out of that sifting process, I hope to identify an account of prerogative that is consistent with core principles of the modern constitution. I set down what I derive from that method in propositional form.

1. Prerogative is the name the constitution gives to a specific bundle of executive powers: 49 those surviving or residual powers that were originally special to the

influence being Montesquieu's De l'esprit des lois [1748] in which England appears as the epitome of the modern republic in which a model of 'extreme political liberty ... is established by their laws': The Spirit of the Laws (Cambridge: Cambridge University Press, 1989, ed. Anne M. Cohler, Basia C. Miller and Harold S. Stone), 166.

${ }^{49}$ See e.g. CCSU (Lord Roskill at 417): 'I am unable to see, subject to what I shall say later, that there is any logical reason why the fact that the source of the power is the prerogative and not statute should today deprive the citizen of that right of challenge to the manner of its exercise which he would possess were the source of the power statutory. In either case the act in question is the act of the executive. To talk of that act as the act of the sovereign savours of the archaism of past centuries.' See also Town Investments Ltd v Department of the Environment [1978] AC 359 (HL). 
king and which engage the executive not in its capacity as executor of the laws but in its capacity as guardian of the state (custodes patriae).

2. Existing conceptions of prerogative share a common root, not fully articulated in them, that prerogative is an expression of peremptory or imperative authority. The exercise of prerogative typically results in a direction or measure and not a law or general norm. 50

3. Whereas with statutes we understand the primary audience to be the legal subject, an exercise of prerogative may be said to be first and foremost directed at officials. ${ }^{51}$ It follows that - absent war $^{52}$ and outside imperial law, both contexts where constitutional rules against domination are less clear and less consistently applied ${ }^{53}$ - an exercise of prerogative can have no meaningful or lasting effect on legal rights and obligations. ${ }^{54}$

4. Prerogative, understood as a mode of peremptory authority, has corresponding analytic properties. It is affective in that the style of decisive leadership it sustains still draws, albeit sotto voce, upon an ideal of kingly rule. As a residual symbol of majesty and lordship, prerogative taps into a sentiment now barely glimpsed and almost shameful to modern constitutional sensibilities, but which is probably more alive than we care to admit. ${ }^{5}$ It has a distinctive form in that it dispenses very largely with the formal requirements and processes that otherwise mark exercises of governmental power. And it has a distinctive function - as a claim to a special power and jurisdiction that represents a primary decisionistic element within the constitution.

5. In practice, these properties tend to operate as a complex whole. The weakening of one element can weaken the whole. In particular, as the affective part of the prerogative diminishes - the direction of travel for a long time - the greater the reliance on functional arguments. ${ }^{56}$ But that move only raises the stakes: why

50 In an early work, Carl Schmitt draws a helpful distinction between measures or decrees, which are situation-specific and action-oriented, and legal norms, which aim to give expression to a legal principle and are thus general in scope, in discussing the powers of the president of the German Reich under Article 48 of the Weimar Constitution: Dictatorship (Cambridge: Polity Press, trans. Michael Hoelz and Graham Ward, 2014), 213-17. Prerogative law-making is not unknown, under certain conditions, in colonial law - see Bancoult (No.2); Campbell v Hall (1774) 1 Cowp 204 - but again, as a juristic structure that maps political domination, this represents the exception that proves the rule.

51 So, even something on the legislative side of the spectrum - such as the British Indian Ocean Territory Order 1965 (S.I. No.1 of 1965) at issue in the Chagos Island cases - is most reasonably read as a set of instructions first establishing and then directing the BIOT Commissioner to perform certain functions rather than a law directed at the population of BIOT (whose existing was in any case intermittently denied by those making the statutory instrument).

52 Even here, the governing idea is that (a) statute is better (and more normal) as a basis for the actions of state agents and (b) while in urgent situations it may be possible through prerogative e.g. to issue regulations that may have a provisional force of law, these need to be confirmed by Parliament: $D e$ Keyser, Burmah Oil.

${ }^{53} \mathrm{R} v$ Secretary of State for Foreign and Commonwealth Affairs, exp Bancoult (No.2) [2008] UKHL 61.

${ }^{54} \mathrm{R}$ (Miller) v Secretary of State for the Home Department [2017] UKSC 5, [50].

55 But see Bagehot, The English Constitution, 30 \& 41.

56 See e.g. Endicott's defence of Blackstone's well-known articulation of the need for prerogative in the field of foreign affairs 'for the sake of unanimity, strength and dispatch'. 
choose prerogative when you can accommodate almost any scenario ${ }^{57}$ within the more constitutionally orthodox form of statute plus regulations?

6. Prerogative operates within ordinary constitutional structures, and these are now densely textured with law. But Locke's point about prerogative's liminal character still has some relevance. Prerogativa regis retains trace elements of the constitutionally illicit in that it arguably retains a (greatly reduced) capacity to probe the boundaries of the constitution. It is too late to create prerogatives, ${ }^{58}$ but the open-textured nature of the category does not entirely preclude the possibility that the executive might make creative use of it to the extent that other elements within the constitution allowed. ${ }^{59}$

Table 2: The Concept of Prerogative

\begin{tabular}{|l|l|l|l|}
\hline & Nature & Figure & Element \\
\hline Prerogative & Directive & $\begin{array}{c}\text { Executive } \\
(\text { Custodes Patriae })\end{array}$ & Complex Whole \\
\hline
\end{tabular}

\section{THE PREROGATIVE TWO-STEP REVISITED}

The first part of the paper identified a 'central case' of prerogative - that is, the strongest version of the concept consistent with existing constitutional fundamentals - by sifting through existing conceptions. In this second part, attention turns to practice. Where possible, the case is pressed that prerogative has ceased to function in a way that is consistent with its central case. But by concentrating on a number of recent UKSC cases this process of testing proceeds in a relatively limited way since a thorough appraisal would necessitate a full survey of not only all the relevant cases, but also developments in other institutions, and these are only briefly recorded here.

57 This development occurred within the context of both (a) war, (b) emergency powers and (c) martial law over a century ago: see e.g. (a) the Defence of the Realm Act 1914 (and subsequent provisions); (b) Protection of Life and Property (Ireland) Act (1871); An Act for the Better Protection of Person and Property in Ireland (1881); Prevention of Crime (Ireland) Act (1883); (c) the creation by statute of a Martial Law Board in the Second African (or Boer) War, discussed in Charles Townshend, 'Martial Law: Legal and Administrative Problems of Civil Emergency in Britain and the Empire, 1800-1940 (1982) 25 Historical Journal 167. For analysis see Thomas Poole, Reason of State: Law, Prerogative and Empire (Cambridge: Cambridge University Press, 2015), ch.6.

${ }^{58}$ BBC v Johns [1965] Ch. 32, 79 (Diplock LJ). But see e.g. the Foreign Jurisdiction Act 1843, which delegated sui generis legislative ('as though colonial prerogative') powers to the Crown with extraterritorial utility, intended to give the Crown the prerogatives associated with conquest where there was none.

${ }^{59} \mathrm{R} v$ Secretary of State for the Home Department, exp Nortbumbria Police Authority [1989] 1 QB 26. A better example perhaps of the re-opening of prerogative comes from Australia: Ruddock $v$ Vardalis (the Tampa Case) [2001] FCA 1329. 
With that qualification in mind, let us turn to the law. Contemporary judicial review principles relating to the prerogative date from the $G C H Q$ case. ${ }^{60}$ The case involved a challenge to the use of the prerogative by the Prime Minister, in her capacity as Minister for Civil Service, to ban workers at signal intelligence headquarters GCHQ from belonging to a trade union. The case stands for the proposition that in principle an exercise of prerogative power is reviewable on ordinary public law grounds. ${ }^{61}$ In Lord Diplock's words: 'I see no reason why simply because a decision-making power is derived from a common law and not a statutory source, it should for that reason only be immune from judicial review.' ${ }^{2}$ But in fact, what the case gives with one hand it all but takes back with the other, such were the riders and qualifications added to the principle. Many prerogatives, the Law Lords agreed, were beyond the reach of the judicial process altogether because review of their exercise would necessarily involve policy considerations. The best-known exclusionary device was Lord Roskill's list of 'excluded categories', that is, those prerogatives that were judged by their nature to be unreviewable. The nonexhaustive list included most of the powers that comprise what I would include in the central case of prerogative: 'the making of treaties, the defence of the realm, the prerogative of mercy, the grant of honours, the dissolution of Parliament and the appointment of ministers'. ${ }^{63}$ Certainly, judges and contemporary commentators would have expected the core principle to evolve. ${ }^{64}$ But there is no sign of anything more than that the judges might be prepared to nibble around the edges of prerogative.

A review of the post-GCHQ case law a decade ago produced a mixed picture. Judicial oversight might have gone further than earlier dicta would have led one to expect; but there was still plenty of deference to prerogative on show. ${ }^{65} \mathrm{I}$ argued that while there had been a genuine movement in a rule-of-law direction, you more often saw the courts performing a 'prerogative two-step'. Step 1, the refusal to countenance the idea of a gap in the normal framework of the law and the assertion that ordinary legal principles apply to prerogative law-making; Step 2, the accommodation of government interests and equivocation or uncertainty in the application of those principles. In other words, courts were disinclined to say that a

60 The previous modern jurisprudence held that the courts would inquire into whether a particular prerogative exists or not, and if it does exist, into its extent. But once the existence and extent of a power are established, the court cannot inquire into the propriety of its exercise: Attorney General $v$ De Keyser's Royal Hotel Ltd [1920] AC 508. The older authorities go back at least as far as Probibitions del Roy (1608) 12 Co. Rep. 63 and the Case of Proclamations (1611) 12 Co. Rep. 74.

61 See Rahmatullah (No.2) and Serdar Mohamed v Ministry of Defence [2017] UKSC 1, discussed below, at [15] (Lady Hale): 'After that case, the exercise of prerogative power might be excluded from the scope of judicial review, not because of its source, whether statute or the prerogative, but because of its subject matter.

62 CCSU, 410. See also Lord Scarman at 407 and Lord Roskill at 417.

63 CCSU, 418.

64 See e.g. Simon Lee, 'GCHQ: Prerogative and Public Law Principles’ [1985] Public Law 186.

65 Poole, 'Judicial Review at the Margins: Law, Power and Prerogative'. In that assessment, I was certainly not alone. See also e.g. Adam Tomkins, Our Republican Constitution (Oxford: Hart Publishing, 2005),

133: in no area of public law 'are the courts as reluctant to review government actions and decisions as when they touch upon the prerogative.' 
challenge to a prerogative was non-justiciable, but were reluctant to decide against the government. Looking back, this was true of $G C H Q$ itself. The court held that the exercise of prerogative was in principle reviewable - employees and trade unionists had a legitimate expectation of consultation - but that national security interests as defined by government took precedence. The government lost on the law, so to speak, but still managed to win at the close.

Many prerogative cases seemed to fit this mould. GCHQ had made inroads into prerogative but had left its basic structure for the most part intact. More specifically, at one level (corresponding to Step 1) the jurisprudence claimed to demystify and normalise prerogative, purporting to treat it as just another executive power (albeit one that in some contexts touched upon matters of political sensitivity). At another level (corresponding to Step 2), it accepted, often covertly or at least quietly, the continued existence of prerogative as a special category of executive power that evoked a special authority to which the court ought to defer. In the application of the law of prerogative then, there was some evidence to suggest the residual pull of the affective dimension of prerogative which, though now denied at the level of general principle, had been so long one of its core elements.

This jurisprudential analysis sat within a broader account of constitutional dynamics that contained two key aspects, both with considerable pedigree: the shrinking of prerogative, taking place largely at the political level but not only there, ${ }^{66}$ typically by turning prerogative into a statutory power; 67 and the normalising of prerogative that occurs largely at the legal level but not only there, typically by subjecting the exercise of prerogative to more searching scrutiny. ${ }^{68}$ What I did not foresee was the pace of change. Examples of shrinkage include putting the right to manage the civil service, at issue in $G C H Q$, on a statutory footing, ${ }^{69}$ and the replacement of the dissolution prerogative through the Fixed-term Parliaments Act 2011. There have been significant normalising moves within Parliament, notably a (nascent) constitutional convention that would require House of Commons approval before armed force may be deployed, ${ }^{70}$ and the increased role for Parliament in the exercise of the foreign relations prerogative. ${ }^{71}$

\footnotetext{
66 A legal example might be $M v$ Home Office [1994] 1 AC 377.

${ }^{67}$ A process discussed in R $v$ Secretary of State for the Home Department, exp Fire Brigades Union [1995] 2 AC 513.

68 See e.g. $R v$ Secretary of State for the Home Department, exp Everett [1989] QB 811 (CA), where Taylor LJ summarised the effect of the $G C H Q$ case as making clear that the powers of the court 'cannot be ousted merely by invoking the word 'prerogative'. See also R $v$ Secretary of State for the Home Department, exp AlFayed [1998] 1 WLR 763.

${ }^{69}$ Constitutional Reform and Governance Act 2010, Part 1, section 3.

70 See House of Lords Constitution Committee, Constitutional arrangements for the use of armed force $2^{\text {nd }}$ Report of Session 2013-14, July 2013); James Strong, 'Why Parliament Now Decides on War: Tracing the Growth of the Parliamentary Prerogative through Syria, Libya and Iraq' (2015) 17 British Journal of Politics and International Relations 604; Philippe Lagassé, 'Parliament and the War Prerogative in the United Kingdom and Canada: Explaining Variations in Institutional Change and Legislative Control' (2017) 70 Parliamentary Affairs 280.

71 See e.g. Constitutional Reform and Governance Act 2010, Part 2 of which enlarges the role for Parliament in the process of ratifying treaties and vesting an express power of veto in the House of
} 
Significant though some of these developments are, it remains possible to fit them into my earlier thesis - that we are witnessing the gradual, if increasingly frequent, reduction of prerogative, the assumption being that ultimately this normalising process would reduce the category to its hard core. But more recent jurisprudential developments question that analysis and make it possible to advance a stronger explanatory narrative. They make it plausible to argue, that is to say, that prerogative has no discernible core.

Exemplary in this regard are four cases handed down in the same week by the UK Supreme Court (UKSC), all of which touched on foreign relations powers. In Miller - the Brexit case - the UKSC upheld the lower court's decision that the government did not have the power under the foreign relations prerogative to give notice to the EU institutions of the UK's intention to withdraw from the EU, since to do so would compromise existing statutory rights. ${ }^{72}$ Much has already been said about the case. ${ }^{73}$ But what is interesting for present purposes is that - contrary to the expectations of many commentators, even those like me who thought that the government should lose on the law - neither court gave any leeway to the argument based on the affective dimension of prerogative, prominent though it was in government submissions. This represents a significant defeat for prerogative since this was a case decided on one of its strongest grounds - foreign relations being unquestionably part of its central case ${ }^{74}$ - and at the sharp end of governmental action. One of the government's documents claimed that the matter was 'of high, if not the highest, policy; a polycentric decision based upon a multitude of domestic and foreign policy and political concerns for which the expertise of Ministers and their officials are particularly well suited and the Courts ill-suited. ${ }^{75}$ In response, the UKSC repeated Lord Reid's description of prerogative as 'a relic of a past age', ${ }^{76}$ while being careful not to deny its functional importance as a ministerial power in the fields of diplomacy and war. ${ }^{77}$ The Court was not remotely persuaded that the category in itself did any work, holding with clarity and conviction that the functional concerns that might be said to support it must be subordinated to the constitutional arguments arraigned against it here. ${ }^{78}$ The judges denied the claim that the prerogative as a category reflects or embodies the custodial function of the executive in relation to which the court should tread warily, an argument that did have some traction among the dissenting judges. ${ }^{79}$

Commons. See also Campbell McLachlan, Foreign Relations Law (Cambridge: Cambridge University Press, 2014), chapter 5.

${ }^{72} \mathrm{R}$ (Miller) v Secretary of State for Exiting the European Union [2017] UKSC 5.

${ }^{73}$ For more of my own thoughts on the case see Thomas Poole, 'Devotion to Legalism: On the Brexit Case' (2017) 80 Modern Law Review 696.

${ }^{74}$ Other inroads have been made into the foreign affairs prerogative: see e.g. R (Abbasi) v Secretary of State for Foreign and Commonwealth Affairs [2002] EWCA Civ 1598; R (Al Rawi) v Secretary of State for Foreign and Commonwealth Affairs [2006] EWCA Civ 1279.

75 'Detailed Grounds of Resistance on Behalf of the Secretary of State' (2 September 2016), s.5(3).

76 Burmah Oil, 101.

77 Miller, [49].

78 Miller, [92].

79 [240] (Lord Reed); [249] (Lord Carnwath). 
The other three cases, handed down together - Belhaj, Rabmatullab and Serdar Mohamed - are less well known but in their own way equally significant. They arise out of the post-2001 counterterrorism climate and target specifically the UK's complicity in the unlawful detention and rendition, assault, torture and cruel and inhuman treatment of individuals usually (in these actions) at the hands of officials of other states. In narrowly doctrinal terms, they engage the category of Act of State, a common law doctrine (or set of doctrines) that shelters from judicial oversight certain kinds of 'sovereign' acts done in the exercise of the foreign relations prerogative and the broadly comparable acts of other states. ${ }^{80}$ Constitutionally speaking, we might invoke Locke to suggest that those doctrines are part of the federative power and, as such, may be conceived if not as part of the prerogative then operating on precisely the same terrain, since both rest in the same hands (the executive) and derive their authority from the same source (its capacity as guardian of the state). This perspective acknowledges that Act of State is part of domestic law not public international law. It also tells us something useful about the legal terrain that Act of State is supposed to help map out. In these terms, Act of State can be understood as a principle (or set of principles) that is partly constitutive of that part of the state which comprehends and acts in the world outside it. As the term federative implies - it is centrally about agreements or pacts (foedera) - this capacity also has a non-domestic dimension. That is, it also patterns legal relations that result principally from the actions of other state agents, but which touch on the legal capacities of the state's own agents. It does so federatively - that is, as though it expects those patterns to be mirrored or replicated in the legal systems of other states (although that may or not be the case in practice, and is not determinative either way). In other words, the federative is unique among domestic constitutional capacities in that it deals with projections of juridical authority from the outside in as well as the inside out.

The first case, Belhaj, engaged the foreign act of state doctrine. ${ }^{81}$ As such, it is an example precisely of the distinctive outside-in operation of the federative just remarked upon. The central issue was UK complicity in actions in relation to which foreign states (in Belhaj's case, the US and Libya) were the prime actors. The government argued that the court should recognise a broad category of foreign acts of state that covered all sovereign acts by a foreign state. The Supreme Court refused to expand the existing categories recognised by the common law - and rejected a parallel international law claim of state immunity - although what those categories are now meant to look like varies from judge to judge. All the judges accepted,

\footnotetext{
${ }^{80}$ For an authoritative analysis see Amanda Perreau-Saussine, 'British Acts of State in English Courts' (2008) 78 British Year Book of International Law 176. There have been important recent Australian jurisprudence on the Act of State doctrine: Habib v Commonwealth [2010] FCACA 12; Motiv The Queen [2011] 245 CLR 456, where French CJ for the majority held that there was no 'general and universally applicable rule that Australian courts may not be required (or do not have or may not exercise jurisdiction) to form a view about the lawfulness of conduct that occurred outside Australia by reference to foreign law' (para 50).

81 Belhaj and Rahmatullah v Jack Straw [2017] UKSC 3.
} 
however, that there were certain acts - torture certainly among them - that could receive no protection from the Act of State doctrine. 82 'The purpose of the foreign act of state doctrine is to preclude challenges to the legality or validity of the sovereign acts of foreign states. It is not to protect English parties from liability for their role in it. ${ }^{83}$

Lord Neuberger seems to attract the most support, although Lord Mance's is arguably the leading judgment. What is clear is that the Court rejected the contention that UK courts were precluded 'from investigating any acts of a foreign state when and if the Foreign Office communicated the Government's view that such investigation would "embarrass" the United Kingdom in its international relations'. ${ }^{84}$ (Although such a statement might be a factor a court would take into account when deciding whether to refuse to determine the issue. ${ }^{85}$ ) That position came with a wider rejection of the straightforward equation between the exercise of sovereignty and the executive branch of the state, not just in the UK but more widely:

In states subject to the rule of law, a state's sovereignty may be manifest through its legislative, executive or judicial branches acting within their respective spheres ... A rule of recognition which treats any executive act by the government of a foreign state as valid, irrespective of its legality under the law of the foreign state ... could mean ignoring, rather than giving effect to, the way in which a state's sovereignty is expressed. ${ }^{86}$

This is an important statement. It insists that the starting proposition within a constitutional state such as the UK must be that federative power is exercised on the basis of legality (or constitutionality) and not on the basis of prerogative (or sovereignty). This proposition only has direct bearing on UK law, of course, but as I said earlier it is a characteristic of the federative that it operates on the assumption that other similar legal orders will mirror or replicate the legal structure of the federative that is being articulated here. This statement does from the outside - and rather more boldly - something that Miller does from within. It dismantles the worldview that sustains the domestic prerogative in a strong sense, that is, the prerogative understood as an imperative and directive constitutional power. That view of the prerogative, when externalised and generalised, fits a model in which sovereign entities interact on the basis of their presumed imperative authority.

\footnotetext{
82 [98] (Lord Mance); [168] (Lord Neuberger); [262] (Lord Sumption).

83 [266] (Lord Sumption), distinguishing R (Noor Khan) v Secretary of State for Foreign Affairs [2014] EWCA Civ 24.

84 [41] (Lord Mance); [241] (Lord Sumption), interpreting Buttes Gas and Oil Co. v Hammer (No.3) [1982] AC 1988. The government relied in particular on Yukos v Rosneft Oil Co. (No.2) [2012] EWCA Civ 855.

85 [149] (Lord Neuberger). Another important diplomatic relations case, albeit arising in a different context with different arguments in play, is $R$ (Corner House) v Director of Serious Frand Office [2008] UKHL 60, where arguments about necessity and national security did trump the rule of law.

86 [65] (Lord Mance). Also [167] (Lord Neuberger).
} 
Instead, the UKSC in Belhaj insists upon a standard for the UK's interaction with other legal orders that corresponds to the UK constitution's own principles.

The second Act of State case, $A l-W$ abeed, concerned an action for damages against the UK government this time alleging unlawful detention and maltreatment by British forces. ${ }^{87}$ The first question concerned whether the UK had authority under relevant UN Security Council resolutions to adopt its own detention policy, above and beyond that already established in Afghanistan under the aegis of the International Security Assistance Force. The Court held that it did. $88 \mathrm{~A}$ second issue related to the applicability of the European Convention on Human Rights (ECHR) to extraterritorial armed conflict. On this matter, the majority preferred the decision of the Grand Chamber in Hassan v United Kingdom over its earlier judgment in $\mathrm{Al}$ Skeini. 89 In Hassan, the European Court of Human Rights rejected the argument that Article 5 (the right to liberty) was displaced in such contexts, but held that it fell to be adapted to a context in which international humanitarian law provided the relevant safeguards against abuse..$^{90}$ Applied to the situation in $\mathrm{Al}$-W aheed, the UKSC found the detention processes deficient on the narrow basis that it failed to provide an adequate and practical means by which those detained could challenge the legality of their detention. ${ }^{11}$ The UK was therefore in breach of its obligations under ECHR Article 5(4).

There is considerable nuance here, as the UKSC tried to grapple with what is an almost intractable predicament. The relevant context is where, pursuant to the exercise of armed force, a signatory to the ECHR has gained some foothold, necessarily incomplete, within a foreign territory. In that context, it is likely to be impossible to guarantee the whole gamut of Convention rights. Does that mean that the only alternative is in effect the disapplication of those rights? Both options have considerable drawbacks. In line with the consistent disinclination in these cases to allow for legal black holes, ${ }^{92}$ the Court preferred an approach that insisted that a core set of rights must apply in extra-territorial conflicts and - equally important that those rights are made meaningful to those who seek to engage them. ${ }^{93}$ The case was decided largely within the framework of European and international human rights law. ${ }^{94}$ Even so, $A l$-W aheed manages to exemplify what now seems normal

87 Al-Wabeed and Serdar Mohamed v Ministry of Defence [2017] UKSC 2.

88 [38] (Lord Sumption). In reaching this conclusion, the UKSC also worked through important points about authorisation in international law, distinguishing the ECtHR's judgment in Al-jedda v United Kingdom (2011) 53 EHRR 23. Lord Mance dissented on this point: [180].

89 Al-Skeini v United Kingdom (2011) 53 EHRR 18.

${ }^{90}$ Hassan v United Kingdom (2014) 38 EHRC 358. Lord Reed (Lord Kerr in agreement) dissented on this point.

${ }^{91}$ [105-6] (Lord Sumption).

${ }^{92}$ See e.g. Belhaj, [30] (Lord Mance): 'The appellants' case on state immunity in this jurisdiction would preclude suit against them anywhere.

93 [67] (Lord Sumption).

94 [148] (Lord Mance): 'the intermeshing of domestic and international law issues and law has been increasingly evident in recent years. Just as States answer for domestic courts in international law, so it is possible to regard at least some domestic court decisions as elements of the practice of States, or as ways through which States may express their opinio juris regarding the rules of international law.' 
when it comes to judging activities within the prerogative/federative zone, where the urge to normalise and juridify is paramount and yet there is still sensitivity in the application of the (new) legal standards to often difficult operational contexts.

The third case, Serdar Mohamed, concerned extensive periods of detention of those initially captured by British forces in Iraq before being handed over to the United States. ${ }^{95}$ This part of the action related to the UK's own treatment of those detained, as opposed to its complicity with other states that was the issue in Belhaj, and so engaged the Crown (or domestic) Act of State doctrine. Building on admittedly 'shaky foundations', ${ }^{96}$ Lady Hale in the leading judgment acknowledged the existence of a 'rule that certain decisions of high policy in the conduct of foreign affairs are non-justiciable'. ${ }^{97}$ She continued, applying the rule to the context before her: 'if act of state is a defence to the use of lethal force in the conduct of military operations abroad, it must also be a defence to the capture and detention of persons on imperative grounds of security in the conduct of such operations. It makes no sense to permit killing but not capture and detention, the military then being left with the invidious choice between killing the enemy or letting him go.' ${ }^{98}$

So far so prerogative-minded, one might say. 'It is necessary that the courts continue to recognise that there are some acts of a governmental nature, committed abroad, upon which the courts in England and Wales will not pass judgment.' ${ }^{\prime 99}$ But there is a sting in the tail. Emphasising the need to keep domestic act of state within very narrow bounds, ${ }^{100}$ Lady Hale concluded:

We are left with a very narrow class of acts: in their nature sovereign acts - the sorts of thing that governments properly do; committed abroad; in the conduct of the foreign policy of the state; so closely connected to that policy to be necessary in pursuing it, and at least extending to the conduct of military operations which are themselves lawful in international law[.] ${ }^{101}$

We need to examine carefully what is going on here. This is an ostensible win for the government - the only win in the quartet of cases examined so far. But it is really (or also) another example of normalisation. On one hand, the Supreme Court appears to accept a category of executive acts that escape the jurisdiction of the court. And yet almost in the same breath, the Court subjects that category to scrutiny that contains most of the core features of proportionality or irrationality review. ${ }^{102}$

\footnotetext{
95 Rahmatullab (No.2) and Serdar Mohamed v Ministry of Defence [2017] UKSC 1.

${ }^{96}$ The only real authority here was Buron v Denman (1848) 2 Exch 167, in which the court shielded Captain Denman from an action for damages for liberating slaves in West Africa.

${ }^{97}[31]$.

$98[33]$.

99 [33].

100 [33].

101 [37], emphasis added. Compare Lord Sumption at [81], which seems to strip the test of some of its proportionality-like features.

102 Irrationality review has been considerably strengthened of late: see e.g. Pham $v$ Secretary of State for the Home Department [2015] UKSC 19; Keyu; R (Evans) v Attorney General [2015] UKSC 21; Kennedy v Charity Commission [2014] UKSC 20. The difference between the new irrationality and proportionality (and
} 
In order to obtain the protection that this Act of State principle affords, the government must show a legitimate aim and it must not only connect the impugned measures to that aim but also show that they were necessary to achieve that aim. The last limb of that test in particular is no trivial hurdle. In any case, the test is identical to that applied to assess the legality of any significant executive decision or action.

\section{GENERAL EXECUTIVE POWERS}

I have argued that the prerogative in its true sense ought to be understood as a special category of executive power that evoked a special authority to which the court ought to defer (the central case). We might say that the initial post-GCHQ cases modified that understanding somewhat, so that prerogative came to be seen as a special category of executive power that evoked a special authority to which the court ought in appropriate cases to defer. But what might one say now, in light of the quartet of recent cases just examined, as well as the other developments referenced earlier? The moderate reading would suggest a further modification from the original position, so we might say that prerogative has now become a special category of executive power that may evoke a special authority to which the court may in appropriate cases defer. ${ }^{103}$ The stronger reading presses the point further so that redefinition becomes deconstruction: prerogative is no special category, just an inchoate set of executive capacities to which deference in general terms ought not to be given.

It may not matter all that much whether the moderate or the stronger interpretation of the prerogative is right. But one difference between them may be that if the courts elect the stronger position over the more moderate one, the harder it is going to be for the executive to get traction in prerogative cases. The reason is simple. Whereas the moderate reading still permits deference, the stronger reading makes deference exceptional and marginal. Underlying this is a minor, but significant difference. The stronger reading presses more vigorously what we might call the claims of constitutional normality. It insists with fewer reservations than the

reasonableness) tests is not clear; but the dominant school of thought is that whereas proportionality is tethered to the presence of a right or rights, irrationality is the test to apply where no right is engaged.

103 Supporters of this view might care to reference the Court of Appeal decision Regina (XH and Another) $v$ Secretary of State for the Home Department [2017] EWCA Civ 4, an unsuccessful challenge to the Home Secretary's use of the prerogative to withdraw passports from those suspected of terrorist links. The Court of Appeal held (distinguishing Miller) that the prerogative in this area had not been entirely displaced by terrorism prevention and investigation measures ('TPIMs') conferred on the Home Secretary by the Terrorism Prevention and Investigation Measures Act 2011. Note, however, that the category of prerogative is doing no work; it is the reason of state argument that is load-bearing. See especially [116]: 'We accept that the fundamental nature of the rights involved in the present case gives rise to a need for a strong justification for any interference. However, we consider that such a justification is clearly made out here. The grounds relied on by the Secretary of State [including in closed proceedings] demonstrate a genuine, present and sufficiently serious threat to a vital national interest.' 
alternative that any special authority claimed by the executive ought to be sourced through more legitimate forms of legal authority - statute principally, 104 but also in the federative context (positive) international law. ${ }^{105}$ Either way, it may be time to stop talking about prerogative altogether. The term obscures more than it elucidates - but then again it has done that for a long time. We should update our legal categories to match our constitutional thinking. Just as we now speak about the executive's general administrative powers as opposed to prerogatives of contract and agency, so too should we ditch prerogative and talk instead about the general executive powers of government.

\footnotetext{
104 The same principle lay at the heart of Al-Rawi v The Security Service [2011] UKSC 34.

105 As somewhat shakily displayed in $A l-W$ abeed. See also the discussion on sources of legal authority and the UK Constitution in Miller, discussed in Poole, 'Devotion to Legalism'.
} 